\title{
The Going-concern Ability Evaluation of Information Transmission, Software and Information Technology Services Industry-Based on the Factor Analysis Method
}

\author{
GaoYacui ${ }^{1, a}$, WangDandan ${ }^{2, b}$ \\ ${ }^{1} X i$ 'an university of science and technology, Xi'an, Shaanxi, China \\ ${ }^{2}$ Xi'an university of science and technology, Xi'an, Shaanxi, China \\ a326619664@qq.com, b1390460767@qq.com \\ WangDandan
}

Keywords: The going-concern ability; Factor analysis; Information and software industry

\begin{abstract}
For continuing operations of enterprises, investors will be according to the current financial position and operating results to predict the future situation and make investment decisions, thus establishing the going-concern ability evaluation system is particularly important. Article selected the information transmission, software and information technology services listed companies as samples, in total 162, analyzing the profit ability, operation ability, solvency, developing capability and cash flow ability, and established going-concern ability evaluation index system from above five aspects for industry mentioned above.
\end{abstract}

\section{Introduction}

Information transmission services, software and information technology industry is in rapid development phase, which have caught the attention of more and more investors, thus the going-concern ability evaluation of this industry can help investors to make the right investment decisions.

Continue as a going concern is to assume that enterprises normal production and business operation activities will continue in accordance with the established goals, namely in the foreseeable future will be not bankruptcy liquidation, also won't massive cuts in business. For the continued operation of the enterprise, investors need to predict the future and make investment decisions through its current financial position and operating results.

If the enterprise have strong going-concern ability, which can explain the enterprise following the basic hypothesis of continuing operations, thus the financial statements will give stakeholders a safe signal; On the contrary, the going-concern ability is weak, showing that bad factors influence its continuing operations, if accounting personnel still make its financial statements on the premise of continuing operations, and submit the relevant financial information, which will makes the stakeholders get false information, and face potential crisis. So, the going-concern ability has a strong relationship with the interests of investors.

\section{Theoretical analysis and the status of the research}

Continuous operation ability can fully reflect the company's overall operation, including debt paying ability, profit ability, operating ability, growth ability and cash flow ability. Debt paying ability refers to the ability to repay debts; Profitability refers to capital appreciation ability, which ensures the investors obtain investment returns; Operation ability refers to the ability of enterprise capital turnover and asset utilization efficiency, which reflects the management level of enterprise and operation effectiveness of assets;

Domestic research on the listed company's ability to continue as a going concern reference to the method of $\mathrm{Z}$ model, owing to a big difference between domestic practical economic environment and foreign, so there is a certain lack of application of this model. On the selection of evaluation index, YuXianbo selected basic level index, enterprise core level index and enterprise integration 
level indicators to build the going-concern ability evaluation index system and evaluation model for our country high-tech enterprise; Liuting selected market share, capital expansion rate, ratio of intangible assets, operating cash flow per share and net rate as the evaluation index to evaluate the going-concern ability of electronic industry. In previous studies of financial performance evaluation, the core competitiveness and operating performance, scholars prefers to use empirical methods in other industries. There is no related research on information transmission, software and information technology services industry. This industry is in rapid development phase, which caught the attention of more and more investors. So this article select the latest data of this industry from 2013 to 2017, in order to reflect the current status of sustainable management of the industry.

\section{Study design}

\subsection{Samples and index selection}

This article selects Information transmission services, software and information technology industry listed company, eliminating ST company, * ST company and data missing company, a total of 162 listed companies as research samples. Based on the above five aspects, this article select fourteen representatively financial indicators.

\subsection{KMO and Bartlett test}

We can judge whether the selected financial indicators is suitable for factor analysis to extract the common factor through KMO inspection and Bartlett test. It can be seen from table 2 that the value of $\mathrm{KMO}$ is 0.687 , showing strong linear relationship between various variables, so the selected financial indicators is suitable for factor analysis. The observed value of Bartlett test is 12017.388 and the corresponding probability value is zero, showing that test results is suitable for factor analysis.

\subsection{Common factor extraction}

We extract common factor whose characteristic root is greater than one with principal component analysis. It can be seen from table 3,we extract totally five factors, and the variance contribution rate reaches $80.120 \%$, which shows that the former five factors provides enough information to explain the original data.

Table 1 Evaluation index

\begin{tabular}{|c|c|c|}
\hline & The index name & A formula to calculate \\
\hline \multirow[t]{4}{*}{ profitability } & Return on equity (X1) & Net profit / The owner's equity \\
\hline & Return on total assets (X2) & Ebit / The average total assets \\
\hline & Sales net interest rates (X3) & Net profit / Sales revenue \\
\hline & Total assets profit margins $(\mathrm{X} 4)$ & Profit total/ The average total assets \\
\hline \multirow{2}{*}{$\begin{array}{l}\text { Operation } \\
\text { ability }\end{array}$} & Accounts receivable turnover (X5) & Profit total / The average accounts receivable \\
\hline & Total asset turnover (X6) & Main business income / The average total assets \\
\hline \multirow{3}{*}{$\begin{array}{l}\text { Debt paying } \\
\text { ability }\end{array}$} & Current ratio $(\mathrm{X} 7)$ & Current assets / Cash flow of business activity \\
\hline & Quick ratio $(\mathrm{X} 8)$ & (Current assets - inventory)/Current liabilities \\
\hline & Asset-liability ratio (X9) & The total liabilities / The total assets \\
\hline \multirow[t]{2}{*}{$\begin{array}{l}\text { Growth } \\
\text { ability }\end{array}$} & Net profit growth rate $(\mathrm{X} 10)$ & $\begin{array}{l}\text { (Net profit this year - Net profit last year) / } \\
\text { Net profit last year }\end{array}$ \\
\hline & Main business profit growth (X11) & $\begin{array}{l}\text { (Main business profit this year - Main business } \\
\text { profit last year) / Main business profit last year }\end{array}$ \\
\hline \multirow{3}{*}{$\begin{array}{l}\text { The cash } \\
\text { flow ability }\end{array}$} & Cash flow ratio $(\mathrm{X} 12)$ & Cash flow of business activity / Current liabilities \\
\hline & Security of debt (X13) & Cash flow of business activity / The total liabilities \\
\hline & Operating income cash ratio (X14) & Cash flow of business activity / Operating income \\
\hline
\end{tabular}


Table $2 \mathrm{KMO}$ and Bartlett test

\begin{tabular}{|c|c|c|}
\hline Sampling & yer measurements & .687 \\
\hline \multirow{3}{*}{ Bartlett test } & The approximate chi-square & 12017.388 \\
\hline & df. & 91 \\
\hline & Sig. & .000 \\
\hline
\end{tabular}

\subsection{The factor named}

It can be seen from table 4 that return on total assets, total assets profit margins, sales net interest rate reach $0.938,0.940$ and 0.859 on factor $F 1$, and the three indexes reflect the profit ability of enterprise, so F1 can be defined as profit ability factor. Current ratio and quick ratio reach 0.960 and 0.959 on factor F2, and the two indexes reflect the debt paying ability of enterprise, so F2 can be defined as solvency ability factor. Operating income security of cash ratio, cash flow ratios and debt in the facto reach $0.857 、 0.887$ and 0.882 on factor F3, and the three indexes reflect the cash flow ability of enterprise, so F3 can be defined as cash flow ability factor. Accounts receivable turnover ratio and total asset turnover reached 0.907 and 0.874 , and the two indexes reflect the operation ability of enterprise, so F4 can be defined as operating capacity factor. Net profit growth rate reaches 0.904 , and this index reflects the development capacity of enterprise, so F4 can be defined as development capacity factor.

Table 3 Characteristic value and the variance contribution rate

\begin{tabular}{|c|c|c|c|c|c|c|c|c|c|}
\hline \multirow{2}{*}{$\begin{array}{l}\text { Ingredien } \\
\text { ts }\end{array}$} & \multicolumn{3}{|c|}{ The initial eigenvalue } & \multicolumn{3}{|c|}{$\begin{array}{c}\text { Extraction of sum of squares } \\
\text { loaded }\end{array}$} & \multicolumn{3}{|c|}{$\begin{array}{l}\text { Rotate the sum of squares } \\
\text { loaded }\end{array}$} \\
\hline & $\underset{\mathrm{n}}{\text { summatio }}$ & $\begin{array}{l}\text { variance } \\
\%\end{array}$ & $\begin{array}{l}\text { accumulat } \\
\text { ion } \%\end{array}$ & $\underset{\mathrm{n}}{\text { summatio }}$ & $\begin{array}{l}\text { variance } \\
\%\end{array}$ & $\begin{array}{l}\text { accumul } \\
\text { ation } \%\end{array}$ & $\underset{\mathrm{n}}{\text { summatio }}$ & $\begin{array}{l}\text { variance } \\
\%\end{array}$ & $\begin{array}{l}\text { accumula } \\
\text { tion } \%\end{array}$ \\
\hline 1 & 4.427 & 31.622 & 31.622 & 4.427 & 31.622 & 31.622 & 2.815 & 20.110 & 20.110 \\
\hline 2 & 2.344 & 16.743 & 48.366 & 2.344 & 16.743 & 48.366 & 2.682 & 19.159 & 39.269 \\
\hline 3 & 2.113 & 15.095 & 63.461 & 2.113 & 15.095 & 63.461 & 2.467 & 17.624 & 56.892 \\
\hline 4 & 1.325 & 9.462 & 72.923 & 1.325 & 9.462 & 72.923 & 2.090 & 14.926 & 71.818 \\
\hline 5 & 1.008 & 7.197 & 80.120 & 1.008 & 7.197 & 80.120 & 1.162 & 8.302 & 80.120 \\
\hline 6 & .896 & 6.398 & 86.518 & & & & & & \\
\hline 7 & .560 & 4.003 & 90.521 & & & & & & \\
\hline 8 & .478 & 3.411 & 93.932 & & & & & & \\
\hline 9 & .384 & 2.744 & 96.676 & & & & & & \\
\hline 10 & .278 & 1.985 & 98.660 & & & & & & \\
\hline 11 & .163 & 1.168 & 99.828 & & & & & & \\
\hline 12 & .012 & .088 & 99.916 & & & & & & \\
\hline 13 & .009 & .061 & 99.977 & & & & & & \\
\hline 14 & .003 & .023 & 100.000 & & & & & & \\
\hline
\end{tabular}

Table 4 The factor loading matrix

\begin{tabular}{cccccc}
\hline & \multicolumn{5}{c}{ ingredients } \\
\cline { 2 - 5 } & 1 & 2 & 3 & 4 & 5 \\
\hline Return on assets & .938 & -.044 & .190 & -.053 & .129 \\
\hline Net interest rate of the total assets & .940 & .053 & .199 & -.059 & .122 \\
\hline Return on equity & .386 & .051 & .041 & -.277 & -.196 \\
\hline Operating profit margin & .859 & .169 & .188 & .019 & .020 \\
\hline Accounts receivable turnover & -.079 & .004 & -.006 & .907 &. .111 \\
\hline Total asset turnover & .004 & -.169 & -.033 & .874 & .056 \\
\hline Current ratio & .041 & .960 & .130 & .009 & .047 \\
\hline
\end{tabular}


Table 4, cont. The factor loading matrix

\begin{tabular}{cccccc}
\hline Quick ratio & .049 & .959 & .139 & .010 & .044 \\
\hline Asset-liability ratio & -.091 & -.754 & -.133 & .201 & .079 \\
\hline Net profit growth rate & .065 & .022 & .007 & -.078 & .904 \\
\hline Operating income growth rate & .147 & -.023 & .002 & -.609 & .493 \\
\hline Operating income cash ratio & .169 & -.067 & .857 & -.039 & -.048 \\
\hline Cash flow ratio & .221 & .318 & .887 & -.009 & .035 \\
\hline Security of debt & .204 & .319 & .882 & -.007 & .037 \\
\hline Extraction method $:$ the main ingredients & & & &
\end{tabular}

\subsection{The factor score}

We calculate the total score of going-concern ability of each company by the main factor weighted characteristic value contribution as weights .Calculation method is as follows:

$$
F=\frac{20.110 \mathrm{~F}_{1}+19.159 \mathrm{~F}_{2}+17.624 \mathrm{~F}_{3}+14.926 \mathrm{~F}_{4}+8.302 \mathrm{~F}_{5}}{80.120}
$$

We can make relevant comments on going-concern ability of enterprise through the analysis of the factor score. Zero is used as the reference benchmark, and composite scores greater than 0 shows that the company in going-concern ability is better. By the statistical data in 2017 , there are fifty-eight companies having better going-concern ability, and accounted for $35.8 \%$ of the total number of samples.

\section{The research conclusion}

We can evaluate the going-concern ability of company from profitability, solvent, cash flow capacity, operation ability and development ability of company through above analysis. Profitability (F1) accounted for $20.110 \%$, which explains profitability is an important part of the continued operation of enterprises and why investors pay more attention to profitability. Solvency (F2) accounted for $19.159 \%$, reflecting the debt situation of the enterprise. Debt management as a management strategy can make up for the shortage of the enterprise's own money, but big proportion of the debt will affect continuous operation of enterprise, so manager should control well the proportion of debt. Cash flow capacity (F3) accounted for $17.624 \%$. It can truly reflect enterprise's profit quality. If strengthen the management of cash flow, the sustainable and healthy development of the enterprise can be guaranteed. Operating capacity (F4) accounted for $14.926 \%$.It reflects the management ability to the total assets and inventory. Development ability (F5) accounted for $8.302 \%$. We can examine the ability of management through income increased year by year or other financing way to obtain money so as to improve the ability of management.

Through the going-concern ability of the listed companies above, we finally summarized five component factors of the cumulative contribution rate was $80.120 \%$, and the close $20 \%$ of the factors are not included. Through the literature research of scholars both at domestic and abroad, we can find that $20 \%$ of the factors are mainly concentrated in the human resources, public relations, technical skills, cultural knowledge and innovation ability as well as uncertainty. If these factors were included in the later study, it will make the evaluation system of going-concern ability more complete and accurate.

\section{References}

[1] ZhuLiangfeng, The Going-concern Ability Evaluation of Industrial Enterprise —CCoal Industry Enterprises as Examples,Finance\&Accounting,vol.11,pp.71-72,2014.

[2] WangXiaozhe,ChaiLiangqi,Wujie, The Going-concern Ability Evaluation of Agricultural Listed Companies in China_Based on Principal Component Analysis, Factor Analysis and Cluster Analysis, Journal of Yangtze University(Social sciences Edition),vol.11,pp.50-55,2016. 
[3] ZhangXuejun,HouJiatong, The Going-concern Ability Evaluation of Manufacturing Listed Companies_-Based on the Factor Analysis Method, Friends of Accounting,vol.8,pp.88-89,2015. 